\title{
Outbound open innovation in bio-pharmaceutical out-licensing
}

\author{
Yansong $\mathrm{Hu}^{\mathrm{a}, 1}$, Peter McNamara ${ }^{\mathrm{b}, 2}$, Damien McLoughlin ${ }^{\mathrm{c}, 3}$ \\ a Warwick Business School, University of Warwick, Coventry CV4 7AL, United Kingdom \\ ${ }^{\mathrm{b}}$ Maynooth University School of Business, National University of Ireland Maynooth, Co Kildare, Ireland \\ ' Smurfit Graduate School of Business, University College Dublin, Co. Dublin, Ireland
}

\section{A R T I C L E I N F O}

Available online 22 August 2014

Keywords:

Outbound open innovation

Out-licensing

Alliance portfolio

Failure experience

\begin{abstract}
A B S T R A C T
Our study investigates the outbound open innovation of firms engaged in technological venturing. Leveraging insights from the sociology theory and innovation literatures, we clarify whether social status helps entrepreneurial ventures overcome market imperfection and information asymmetry in outlicensing and illustrate the importance of specific aspects of social status building in this context. We also examine the effect of failure experiences on out-licensing. We take a dynamic view of desorptive capacity by studying an entrepreneurial venture's learning process, both internally, in terms of its own technology trajectory, and externally, through inter-organizational alliances. We apply a negative binomial model to our novel panel of 180 firms studied over an 18-year period with controls for stocks of clinical development activities, patenting and prior licensing activities. Empirical analysis enables us to observe the impact which the firms' technological and development status, reputation and desorptive capacity exert upon out-licensing volume. Prior outbound open innovation studies do not account for the heterogeneity of technology and R\&D success and failure experiences observed in our study. We also demonstrate the contingency effect of external learning from alliances during the building-up of a firm's desorptive capacity, or the way in which the number of co-authoring partners in scientific publications negatively moderates the positive effect of the number of commercial alliances on the volume of its outlicensing deals. Our findings contribute to the understanding of external knowledge exploitation and complement important aspects of the literatures on outbound open innovation and desorptive capacity, offering empirically rich insights for bio-pharmaceutical firms into the drivers behind volumes of outlicensing deals.
\end{abstract}

Crown Copyright $\odot 2014$ Published by Elsevier Ltd. All rights reserved.

\section{Introduction}

The concept of open innovation (Chesbrough, 2003) has recently gained widespread research attention (e.g., Enkel et al., 2009; Giannopoulou et al., 2010; Groen and Linton, 2010; Huizingh, 2011). Earlier open innovation research focused on inbound processes, whereas outbound processes have received less attention (Mortara and Minshall, 2011). Outbound open innovation, such as out-licensing, is an inside-out process and includes opening up the innovation process to external knowledge exploitation (Mortara and Minshall, 2011). Through out-licensing a firm not only gains economic benefits from the commercialization of technological knowledge, but also achieves strategic nonmonetary benefits, including gaining access to external knowledge,

E-mail addresses: Yansong.Hu@wbs.ac.uk (Y. Hu), peter.mcnamara@nuim.ie (P. McNamara),

Damien.McLoughlin@ucd.ie (D. McLoughlin).

1 Tel.: +44 247652 3915; fax: +44 2476524628 .

2 Tel.: +35317086626.

3 Tel.: +35317168890 . establishing industry standards, and acquiring freedom to operate based on cross-licensing agreements with other firms (Arora et al., 2001; Grindley and Teece, 1997).

We address recent calls in Technovation to use the concept of open innovation to develop new insights into the processes of knowledge creation and exploitation and integrate an open innovation perspective in an interdisciplinary manner (Huizingh, 2011; Van de Vrande and de Man, 2011), in our case drawing upon the literatures on social status in the market for technologies (Arora and Gambardella, 2010; Podolny, 1993) and on the desorptive capacity of firms (Helfat et al., 2007; Müller-Seitz, 2012). We address the gap whereby despite the importance of external knowledge exploitation for firms across different industries, outbound open innovation, such as out-licensing, has remained relatively neglected. In particular, it is not clear why some firms are able to achieve a higher number of out-licensing deals than others, in spite of the various challenges involved and the significant complexity and high attrition rate of this innovation activity (Bianchi et al., 2011a; Gambardella et al., 2007).

An illustrative example from our dataset on the development of a value capturing (revenue generating) out-licensing strategy is 
that of San Diego based Ligand Pharmaceuticals. Under CEO John Higgins, Ligand, a firm with less than 20 employees, has been pursuing a strategy that focuses on increasing licensing, milestone, and royalty fees from its partners. It intends to generate more opportunities to develop successful drugs by forging partnerships with large pharmaceutical companies. This strategy has proved to be a success in achieving a large number of drug out-licensing deals, often more than 20 each year. While building partnerships with pharmaceutical companies has contributed to the success of the firm in securing many out-licensing deals, we ask the question: are there any other factors that are at work in driving outlicensing deals? The answer to this question is important, since the capability levels of different firms in technology out-licensing tend to differ strongly, and these differences further underscore the lack of research on licensing capabilities which are "both relevant and understudied" (Fosfuri and Giarratana, 2010, p. 771).

\section{Research context, questions and contributions}

The context of our research is the bio-pharmaceutical industry, a fertile ground for the adoption of open innovation (Bianchi et al., 2011a) and a sector in which outbound open innovation such as out-licensing is of particular importance.

Out-licensing can play a critical role in accessing the diverse sources of innovation in the new pharmaceutical R\&D landscape (Allarakhia and Walsh, 2011). It also helps in bridging the widening gap between the amount of internally generated drugs for clinical trials by large-scale pharmaceutical firms (Paul et al., 2010), which have commercialization needs and world-class capabilities, and the generation of novel compounds by entrepreneurial bio-pharmaceutical firms, which focus on R\&D-related activities along the value chain in the bio-pharmaceutical industry (Stuart et al., 2007). To explain the differences in the number of new out-licensing deals secured by bio-pharmaceutical firms, we use a longitudinal panel dataset for the out-licensing deals undertaken by 180 publicly quoted bio-pharmaceutical firms from Europe and North America over an 18-year period. Our empirical testing is based on a conceptual model for the out-licensing of new technology driven by market imperfections, information asymmetries, and desorptive capacity, controlling for classical issues such as firm size and technological and clinical R\&D stocks.

This paper seeks to make three contributions to the literature on outbound open innovation. First, we seek to clarify the relationship between social status in the generation of public (scientific publishing) and private (patenting) knowledge about innovation on the one hand and the volume of outbound open innovation licensing undertaken by firms on the other. In doing so, we address two questions: (1) Does social status help entrepreneurial firms overcome market imperfection and information asymmetry with a view to the commercialization of technological knowledge? (2) If so, how much do specific aspects of social status building matter?

Our second contribution from this study is that of investigating the factors directly influencing firms' ability to actually license out knowledge. In this regard, we move one step beyond previous studies on desorptive capacity (namely, Bianchi et al., 2011a) in that we adopt a dynamic view of desorptive capacity by examining the learning process of an entrepreneurial venture, both externally, through its inter-organizational alliances, and internally, in terms of its own technology trajectory.

Our third contribution to the literature is on the relationship between failure experience and the performance outcomes of firms. The relationship between failure and performance in the organizational literature is paradoxical: failure both improves and impedes performance outcomes over time. On the positive side, the literature reports a positive relationship between failure experience and organizational transformation (McNamara and Baden-Fuller, 1999) which improves firms' ability to adapt to environmental changes and improve organizational reliability (Carmeli and Schaubroeck, 2008). However, the literature also finds that failure experience can have negative consequences for performance in that greater experience of firm failure is associated with rising costs (Baum and Dahlin, 2007). Success is positively rewarded and failure is viewed negatively by peers (Edmondson, 2011). Therefore, it is not clear how failures in the R\&D portfolio of an entrepreneurial firm affect the number of out-licensing deals it can achieve. Our research will bring more empirical clarity to this issue.

The rest of the article is organized as follows. Section 3 provides a short overview of the background to our research and theories pertaining to it, and in Section 4 we formulate our hypotheses. Section 5 describes our data, variables and methodology. Section 6 presents the results. Finally, Section 7 discusses the implications of our results, summarizes our findings and suggests avenues for future research.

\section{Literature review: Outbound open innovation and out- licensing in the bio-pharmaceutical industry}

In recent years open innovation has swept through a number of industries (Gassmann et al., 2010). Thus far, research on open innovation processes has focused on distinguishing between the 'outside-in' and the 'inside-out' processes of open innovation, along with their coexistence (Enkel et al., 2009).

Outbound open innovation, in particular technology out-licensing, remains a challenge for most firms. A recent survey on inventors in Europe identifies a worrying 40\% attrition rate between the decision to out-license a technology and the actual conclusion of the deal (Gambardella et al., 2007). The difficulty in achieving out-licensing stems from the high complexity of this activity, which deserves detailed research attention.

Two streams of literature which are particularly rich in insights about outbound open innovation are theories on social status in the market for technologies (e.g., Arora and Gambardella, 2010) and work on desorptive capacity in outbound innovation (Helfat et al., 2007); these are discussed below.

\subsection{The role of status}

The characteristics of technology-intensive environments pose specific challenges to licensing exchange, and markets for knowledge are characterized by market imperfection and information asymmetries concerning the quality of the technology offered for license (Akerlof, 1970; Zeckhauser, 1996). Uncertainty about the value of technology hinders the development of a market for technology (Arora and Gambardella, 2010). Limited transparency and serious inefficiencies in the technology market impede the identification of potential partners, and both the process of negotiation and contracting with partners (Williamson, 1975). "Parties typically do not know who owns what, and who might be interested in trading" (Teece, 1998, p. 68). No licensee firm can be aware of all technological opportunities, let alone process all of the available information about new technological opportunities. Even if the licensee is aware of a certain technological opportunity, it faces a great deal of uncertainty regarding the value and applicability of the technology in question (Arora and Gambardella, 2010; Jensen and Thursby, 2001; Kani and Motohashi, 2012). Licencing a technology across firm boundaries is complicated due to cognitive, intangible, idiosyncratic and predominantly tacit nature of technological knowledge. These features complicate disclosure of this knowledge, in addition to valuation of 
the technology for trade by both parties in a negoitation and the process of marketing this licence (Teece, 2000).

The choice of a potential licensor is therefore overly complex because limited information is available (Jensen and Roy, 2008). Prior research suggests that social status, defined by the prestige accorded to actors because of their social positions (Burt, 1982; Gould, 2002), help simplify partner choice (Jensen and Roy, 2008). In the choice of exchange partners, status shapes firms' choice set of actively considered alternatives.

Formal and informal networks have traditionally played an essential role in compensating for the lack of market transparency (Bidault and Fischer, 1994; Ford and Thomas, 1997). Thus, the commercialization of knowledge assets is fundamentally social in nature (Hoegl and Wagner, 2005; Podolny and Stuart, 1995). Social status can serve as a sign of quality in terms of the resources or capabilities of firms and individuals. Social status positively affects the collective perceptions of potential partners with regard to the focal firm and its outputs (Perrow, 1961) in particular, when information about the firm's actual quality or trustworthiness is unavailable or only imperfectly observable (Jensen, 2003; Podolny, 1993, 2005; Stuart et al., 1999).

Taken as a whole, in technology markets, entrepreneurial firms which are potential licensors may employ the strategy of building their social status as signals to potential commerical partners that they are trustworthy partners despite both their relative inexperience (the liability of newness) and the presence of asymetric information on their capabilities to deliver solutions to customers and partners (Rao et al., 2008).

\subsection{Desorptive capacity in outbound open innovation}

The concept of desorptive capacity is the second stream of research from which our insights into the drivers of out-licensing emerge. This literature merges the concepts of absorptive capacity, which was so central to the innovation literature of the 1990s, with the dynamic capabilities literature, which drove much of the strategy literature of the 2000s, developing a capability-led approach to research on open innovation. Desorptive capacity is a type of dynamic capability as a firm purposely creates, extends, or modifies its resource base (Helfat et al., 2007). Dynamic capabilities can be disaggregated into sensing, seizing, and transforming capacity (Teece, 2007). In the context of out-licensing, sensing capacity relates to identifying new opportunities for licensing. As discussed previously, the problem of information asymmetry prevails in the technology market. Information asymmetry runs in both directions: the licensee lacks knowledge about the specifics of the technology, while the licensor lacks knowledge about the market potential of the technology. Thus, a capacity for sensing is important for identifying potential market opportunities for out-licensing. Beyond sensing capacity, seizing capacity refers to the act of addressing these opportunities. Transforming capacity relates to reconfiguring a firm's processes.

Extant research also suggests that the accumulation of desorptive capacity is a learning process that requires exploitation and exploration; whereas exploitation is associated with activities such as "refinement, efficiency, selection, and implementation", exploration refers to notions such as "search, variation, experimentation, and discovery” (March, 1991, p. 102). Exploration may need to destroy cognitive barriers regarding technology and product areas (Eggers and Kaplan, 2009) and help firms to considerably broaden their perspective on technology commercialization opportunities.

An entrepreneurial venture can build a strong desorptive capacity in at least two ways. The first is through alliances with various external partners. In the context of the bio-pharmaceutical industry, the types of partners with which a firm enters into relationships vary substantially throughout the different phases of the R\&D process (Bianchi et al., 2011a), and the types of partners in alliances are pathways for the exchange of resources and signals that convey recognition (Stuart, 2000). Another way for an entrepreneurial firm to build strong desorptive capacity in outbound open innovation is by learning from its own technological trajectory (Dosi, 1982). Here, innovation can be defined as a cumulative process of incremental problem-defining and -solving activities (Rosenberg, 1982). As many problems are firmspecific, a firm's learning experience is distinctive. Due to the distinctiveness and cumulativeness of a firm's learning experience, its technological trajectory can be characterized as unique and path-dependent (Dosi, 1982; Garud and Karnoe, 2002). Cantwell (2004) has found that, even over time periods of 100 years, most firms continue to develop competencies in technology fields in which they gained their initial technological competencies. Consequently, firms' current technology portfolios are, at least partly, a reflection of their past problems, interests and capabilities. It follows that an entrepreneurial venture's sizable R\&D portfolio may indicate its strong R\&D capability and may also relate to outbound open innovation, since a firm's volume of technological knowledge determines its technology transfer potential.

This brief analysis suggests that in order to explain differences between bio-pharmaceutical firms in terms of the number of new out-licensing deals, the framework underlying our research should comprise two main perspectives: technology market imperfection and information asymmetry, where firms' social status matters, and desorptive capacity in open innovation, where external and internal learning is important. Our discussion leads us to derive a number of specific hypotheses which we posit below.

\section{Hypotheses}

\subsection{Market imperfection and information asymmetry: Social status}

In the market for technologies, firms with high status enjoy several benefits as a result of their perceived quality (Merton, 1968). First, high-status firms are more sought-after as exchange partners because association with high-status actors also boosts the status of the partners (Dacin et al., 2007; Podolny, 1993; Stuart et al., 1999). High-status firms also enjoy legitimacy and respect from others as a result of their favoured standing in the social hierarchy (Gould, 2002). Finally, high status provides firms with favourable access to resources such as financial capital (Stuart et al., 1999) and human capital (Phillips and Zuckerman, 2001; Podolny, 1993). Specifically, entrepreneurial ventures may establish status in two interrelated and yet different spheres: public and private knowledge domains.

Achieving high status in the public knowledge domain (measured by the number of citations) and thus actively connecting to the wider scientific community confers at least two benefits on an entrepreneurial venture: (1) technical credibility, suggesting that the entrepreneurial venture can convey to potential licensees that it understands and can work with the latest scientific ideas in the field (Zucker et al., 1998); (2) some assurance that the firm has the ability to absorb and leverage new knowledge acquired from outside entities (Cohen and Levinthal, 1990).

In the private knowledge domain, biotechnology firms maintain key patents that can reap significant value by licensing their intellectual property rights to other firms developing complementary technologies. A robust patent regime (such as that available to the bio-pharmaceutical industry) enables entrepreneurial firms to convert their research innovations into a valuable resource that can be commercialized via out-licensing (Levitas and McFadyen, 2009). Recent research has demonstrated the link between patent citations and the market value of a patent (Nair et al., 2011). This is 
congruent with previous research, which suggested that the economic value of patents is highly skewed (Griliches, 1990; Harhoff et al., 1999). Therefore, researchers now use the number of citations that a patent receives as a proxy for the true value of patents (Fleming and Sorenson, 2001). In line with this approach, patent citation count can be a relatively accurate indicator of status in the private knowledge domain. A large number of patent citations implies a high status in the private knowledge domain, and signals to potential partners that the patents underpinning the firm's out-licensing activities are likely to generate positive economic returns. We would therefore expect that firms with high patent citations ought to complete more out-licensing deals, as these attract commercial partners focused on capturing economic value from the patented technology. Taking together the arguments on social status in both public and private knowledge domains and its positive relationship with out-licensing, we expect that:

$\mathbf{H}_{\mathbf{1}}$. For an entrepreneurial firm, social status is positively associated with the number of out-licensing deals which the firm secures.

\subsection{Desorptive capacity}

Alliances with established players can help an entrepreneurial firm to build up technological and market knowledge necessary for out-licensing. In particular, prior studies have suggested that establishing alliances is an effective means of balancing and synchronizing the exploitative and exploratory activities (e.g., sensing market opportunities of technologies) required in out-licensing (Holmqvist, 2004; Lavie and Rosenkopf, 2006; Rothaermel and Deeds, 2004). In addition, a portfolio of commercial alliances helps the entrepreneurial venture overcome uncertainty from licensees about its capabilities and its inexperience in developing and transferring new technologies (e.g., seizing and transforming capacity in out-licensing).

For entrepreneurial biotechnology firms, we distinguish between two types of alliances located in both public and private knowledge domains: co-authoring partners in scientific publications versus commercial partners in drug discovery. Scientific papers are the public dissemination of a knowledge creation process by co-authoring partners. Drug discovery and clinical trials is a method through which the intellectual property of partners is generated and converted into products that can capture private economic gains. We expect that alliances in both private and public knowledge domains may be positively correlated with a higher number of out-licensing deals (Cockburn et al., 1999; Pisano, 1997). More specifically:

$\mathbf{H}_{2}$. For an entrepreneurial venture, the number of commercial alliances is positively associated with the number of out-licensing deals which the firm secures.

$\mathbf{H}_{3}$. For an entrepreneurial venture, the number of co-authoring partners in scientific publications is positively associated with the number of out-licensing deals which the firm secures.

In fact, firms' involvement in a wide array of alliances has become a ubiquitous phenomenon in today's business landscape (Contractor and Lorange, 2002). As a consequence, most firms are engaged in multiple simultaneous alliances with different partners and are facing the challenge of managing an entire alliance portfolio (Bamford and Ernst, 2002; Gulati, 1998; Hoffmann, 2007). Prior research implies that interdependencies can occur in alliance portfolios (Vassolo et al., 2004) and thus have the potential to create synergies (Powell et al., 1996). For example, access to universities may enhance the research productivity of private firms.
However, studies on alliance portfolio management also point to the effect of conflict, redundancy or competitive overlap between alliances and partners in the portfolio (Gimeno, 2004; Gomes-Casseres, 1996; Silverman and Baum, 2002). Conflict between partners occurs when they affect one another negatively because they are members of different knowledge domains which may compete against each other. In the public domain the knowledge produced by R\&D is like a public good, which spills easily from the innovating firm to other companies that can free-ride on its efforts (Arrow, 1962). In the private domain there exists the intellectual property's innate value rivalry, thus, disclosing an idea to some, substantially reduces its value for others (Gans and Stern, 2010). Therefore, the conflict between alliances in the public and private knowledge domains is almost inevitable.

In addition, the simultaneous adoption of a wide variety of alliances also triggers costs that might negatively influence the innovation performance of the firm. Numerous alliance governance scholars (e.g., Gulati and Singh, 1998) stress that managing alliance partnerships requires substantial monitoring and control activity. It is argued that as the diversity of alliances partners goes up, firms increasingly need dedicated alliance functions to manage potential conflicts among the different alliances (Hoffmann, 2007; Parise and Casher, 2003).

Based on these arguments, the present study hypothesizes the existence of a negative interactive relationship between publicand private-domain alliances on the number of out-licensing deals, reflecting the costs of simultaneously collaborating with different kinds of partners.

$\mathbf{H}_{4}$. For an entrepreneurial firm, the number of co-authoring partners in scientific publications negatively moderates the positive effect of commercial alliances on the number of out-licensing deals which the firm secures.

The path-dependent nature of absorptive capacity is widely acknowledged (Cohen and Levinthal, 1990). To accumulate strong desorptive capacity in outbound open innovation, a firm can learn from its own technological trajectory (Dosi, 1982). Specifically, a firm may benefit from its market knowledge that is developed in its internal innovation activities. If a firm carries on a reasonably large R\&D portfolio connected to a wide variety of technology markets, it may have a relatively good understanding of many potential applications of these technologies.

Therefore, internal technology development and outward technology transfer are likely complementary because there may be synergies between internal and external technology exploitation in multiple markets. The size of an entrepreneurial venture's R\&D portfolio may be positively associated with outbound open innovation. Conversely, prior research implies that working on very few projects at any given time may suggest weak desorptive capacity, since working on too few ideas diminishes the spillovers in knowledge that can arise when several ideas interact (Irwin and Klenow, 1994). Such spill-over effects exist only when multiple ideas are considered simultaneously (e.g., Bluedorn et al., 1992). Therefore, maintaining a reasonably large R\&D portfolio may be positively associated with outbound open innovation.

Desorptive capacity is built upon the learning process where both exploitation and exploration are needed for searching for, and discovering potential market opportunities for the technology portfolio of a firm. However, exploitation and exploration are two fundamentally different learning activities between which firms divide their attention and resources. Several scholars maintain that there is a trade-off between aligning the organization to exploit existing competencies and exploring new ones (Ancona et al., 2001; Levinthal and March, 1993). 
Scholars have long believed that a well-balanced combination of the two types of learning is essential for long-term organizational success (Gupta et al., 2006; Levinthal and March, 1993). Both types of strategy processes compete for scarce resources. As a result, company leaders need to make trade-offs between them (Burgelman, 2002). Therefore, for firms with similar technological breadth (or heterogeneity in terms of their technology portfolio), having too many projects may be bad for desorptive capacity and thus for achieving out-licensing deals. Theories on capacitysharing suggest that working on too many tasks simultaneously causes less attention to be paid to any individual task (Navon and Gopher, 1979). Bottleneck theories argue that when multiple tasks need the same resources at the same time, bottlenecks arise and all tasks are damaged (DeJong, 1993; Pashler, 1994). Cross-talk arguments suggest that some tasks may produce outputs harmful to the processing of other tasks (Navon and Miller, 1987). Such deleterious effects can increase with the growing number of tasks (Kinsbourne, 1981). Overall, these arguments suggest that processing too many tasks at the same time is likely to lead to lower performance output in innovation (Chandy et al., 2006).

Empirically, the above arguments are also supported by the emerging trend of licensing deals in the industry (Business Insights, 2009). In particular, licensing deals will continue to become more complex due to bio-pharmaceutical firms' desire to remain involved in their product lifecycle beyond the stages of discovery and development. With licensing deals increasing in complexity, obviously, processing too many tasks at the same time is likely to lead to lower performance output in innovation.

Furthermore, recent increases in bio-pharmaceutical firms' consolidation and convergence of domains are an indicator of the ability of well-established bio-pharmaceutical firms to effectively compete against traditional big pharmaceutical firms (Business Insights, 2009). As a result, these bio-pharmaceutical firms with a relatively large R\&D portfolio may become less likely to out-license their crown jewels to their competitors.

Integrating these arguments, we propose that the number of $R \& D$ projects a firm is working on at any given time has an inverted U-shaped effect on the number of its out-licensing deals:

$\mathbf{H}_{5}$. There exists an inverted U-shaped effect between the size of an entrepreneurial firm's R\&D portfolio and the number of its outlicensing deals.

\section{Data}

\subsection{Sample, measures and model specification}

Our sample resulted from a larger sample of the top 300 public bio-pharmaceutical firms in terms of R\&D clinical activity from the Pharmaproject database. Due to our substantive interests in the licensing behaviours of entrepreneurial ventures, we used the following filters to come up with our final sample: the sample firms needed to have a maximum age of less than 20 years, they had to be listed on a stock exchange in North America or Europe, and have data on all of our sources (see below). These filters led to a final sample of 180 firms. We collected all the information on the variables for the 180 firms, as illustrated by the descriptive statistics in Table 1.

Our data were collected from five databases: Pharmaprojects is a database of firms which have been undertaking human therapeutic clinical trials since 1990; Derwent Innovations Index is a database of patenting activity, while Research Insight is an industry standard database for finance and accounting researchers; Thomson Reuters Web of Science Citations Index is a database from which we can record the volume of publication activity and citations of our panel of firms; LexisNexis is a database with over

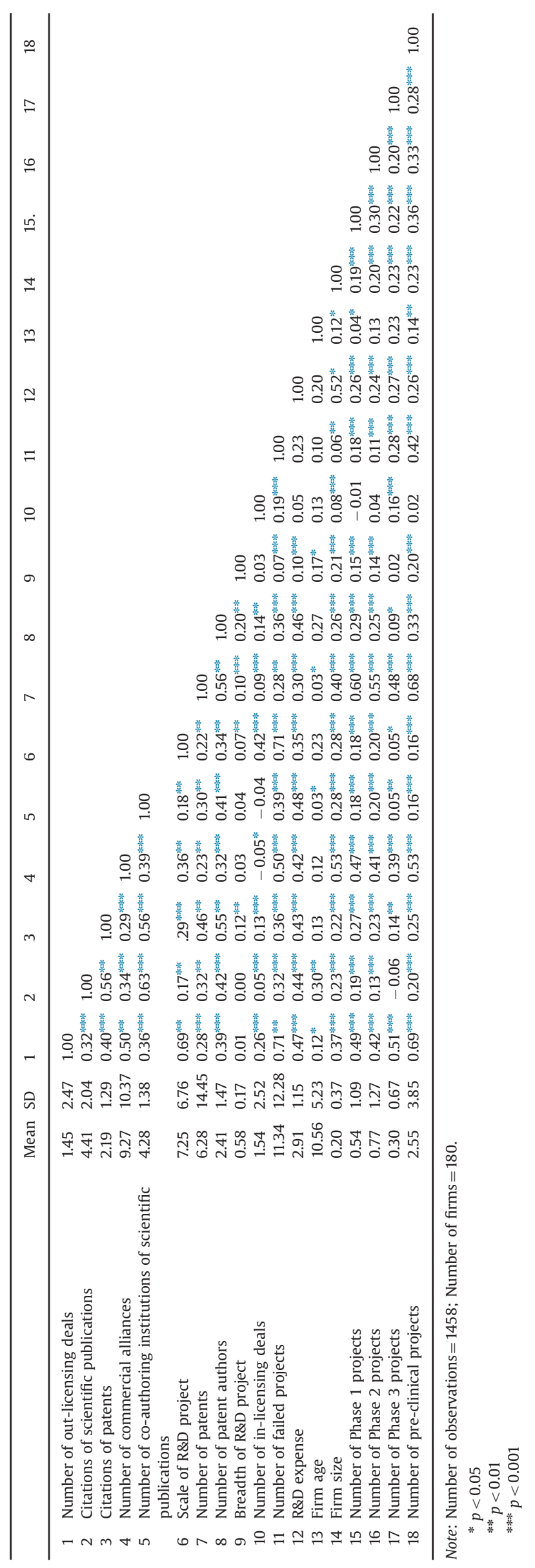


12000 international news sources, from which we counted the number alliance announcements by our firms.

One restriction of the study sample is that all firms are public. This restriction allows us to derive firm-relevant financial information from Research Insight, but it inhibits the generalization of the study results to entrepreneurial ventures. To detect any other possible biases, we further compared the 180 firms in the sample with the other 31 randomly selected entrepreneurial biotechnology firms for which we had gathered incomplete information. This comparison reveals no significant differences in terms of patent productivity, profitability, number of employees, or number of licensing deals. However, the firms in the sample are somewhat more R\&D-intensive, as their average R\&D expenditures are higher than those of the firms that were not included in the final sample.

The different measures used in the study are discussed below. We acknowledge that we cannot fully measure market imperfection and desorptive capacity. We lag all independent and control variables (except firm age) by a year, as our theoretical approach is based on the argument that the volume of current out-licensing is driven by the previously accumulated resources and capabilities of the firm.

\subsection{Dependent variable}

\subsubsection{Total number of out-licensing deals}

Our main interest in this study is to understand why some firms are able to achieve a higher number of out-licensing deals than others, in spite of the various challenges and the high complexity and high attrition rate of this innovation activity (Gambardella et al., 2007). Therefore, we used the aggregate total number of out-licensing deals secured by each firm in a given year. We collected these data from the Pharmaprojects database. A criticism of this measure could be that it does not differentiate the economic value of each deal. Whilst we acknowledge that our measure does not control for this variance, economic benefits only partially explain why firms go for out-licensing (Arora et al., 2001; Grindley and Teece, 1997). A prior study suggests that deal value in licensing is often determined by subjective factors, such as the total perceived economic and technical value of the services or products offered to the licensee (Arnold et al., 2002). Therefore, data on the economic value of each deal can sometimes be noisy.

\subsection{Independent variables}

\subsubsection{Status of a firm}

This construct is composed of two variables: status measured by the number of citations of scientific publications of a firm and status measured by the number of citations of a firm's patents. For the first measure, we used the lagged yearly number of citations (non-cumulative and logged) of the scientific papers published by a sample firm. These data were collected from the Thomson Reuters Web of Science Citations Index. For the second measure, we used the lagged yearly number of citations (non-cumulative and logged) of the patents owned by the firm. These data were collected from the Derwent Innovation Index. As a robustness check, we also used the cumulative counts of the two measures. The results remain largely unchanged, except that the models with non-cumulative measures have a better model fit than the cumulative ones.

\subsubsection{Number of commercial alliances}

To measure this variable for a sample firm, we used the lagged cumulative count of its announced commercial alliances from LexisNexis.
5.3.3. Number of co-authoring institutions of scientific publications

We used the lagged cumulative total number of co-authoring institutions with which a sample firm publishes scientific papers each year. These data are garnered from the Thomson Reuters Web of Science Citations Index database, which allowed us to search for each organization and provided information on when a firm published a paper. Papers published by an author who was not yet a firm employee were not included in the analysis.

\subsubsection{Scale of $R \& D$ portfolios}

We used the lagged (non-cumulative) number of R\&D projects owned by a firm each year to measure this variable. These data were collected from the Pharmaprojects database. As a robustness check, we also used the cumulative count of this measure. The results remain largely unchanged, although the models with noncumulative measure have a better model fit.

\subsection{Controls}

\subsubsection{Number of patents}

The number of patents held by a firm may influence the volume of its out-licensing deals. To control for this effect, we used the lagged (non-cumulative) number of patents owned by a firm each year to measure this variable. To validate the robustness of the reported results, we also used the cumulative count of this measure. The results remain unchanged.

\subsubsection{Number of patent authors}

We used the lagged (non-cumulative) number of patent authors for a focal firm each year to measure this variable. As a robustness check, we also used the cumulative count of this measure. The results remain unchanged.

\subsubsection{Technological breadth of $R \& D$ portfolios}

The breadth of $R \& D$ project portfolios can impact the total number of out-licensing deals. To control for this effect, we used the lagged Blau index (a measure of heterogeneity) of the patent portfolio upon which the R\&D projects of a firm are based each year. There are 14 major biotechnology categories in the Derwent Patent dataset. A score of 0 means that all patents upon which a firm's R\&D is based, come from a single technological category in the Derwent Innovation Index Patent dataset. When Blau equals 1 , there are an equal number of patents from all possible technology classes.

\subsubsection{Number of in-licensing deals}

In the context of open innovation, technology transactions may involve mutual technology transfer in both directions, and the number of in-licensing deals may lead to a higher or lower number of out-licensing deals. To control for such an effect, we counted the yearly non-cumulative number of in-licensing deals of a firm. These data were taken from the Pharmaproject database.

\subsubsection{Number of failed projects}

To measure this variable, we used the lagged cumulative number of ceased projects owned by a firm each year. These data were collected from the Pharmaprojects database. To ease the concern that some firms may have a larger portfolio of projects, we also measure this variable as a percentage, that is, lagged cumulative number of ceased projects divided by the total number of projects owned by the firm, and the results remain unchanged. However, the model fit of count measure is better. 


\subsection{6. $R \& D$ expenditure}

We used the lagged yearly R\&D expenditure of the firm, taken from Research Insight.

\subsubsection{Firm age}

We consulted the websites of all firms in our sample to register the year of founding and calculated the age of each firm; all data from Pharmaprojects was then collected from the year of foundation, or 1990 for firms founded prior to that year, generating a yearly panel of data for each firm.

\subsubsection{Firm size}

Because the number of $R \& D$ projects a firm secures is likely to vary depending on its size, we control for this empirically by using the lagged total number of employees of the firm. These data were taken from Research Insight and are updated yearly.

\subsubsection{Number of $R \& D$ projects at different phases of drug discovery}

The $R \& D$ process is relevant for outbound open innovation. More specifically, in the bio-pharmaceutical industry, outbound open innovation occurs mainly during clinical tests and postapproval activities. In some cases, commercial exploitation may start earlier than the end of pre-clinical tests (Bianchi et al., 2011a). Therefore, we used lagged cumulative measures to control for R\&D projects located in different phases of drug discovery. We took these data from the Pharmaproject database and updated them yearly.

\subsection{Model specification}

For the model specification, the dependent variable is a count variable: the yearly number of biotechnology firm's out-licensing deals. Because we observe over-dispersion in the data (violating the equality of mean and variance assumption in Poisson estimation) we specify a negative binomial model (e.g., Hausman et al., 1984). Furthermore, we used the generalized estimating equations (GEE) (Zeger and Liang, 1986) method, which is being increasingly used to analyse longitudinal and other correlated data, especially when they are binary or in the form of counts. Besides the seeking of more efficient estimators of regression parameters, the main benefit of GEE is the production of reasonably accurate standard errors, hence confidence intervals with the correct coverage rates. In the analysis, we mean-centred the scale of $R \& D$ portfolios variable. To address the issues of non-normality, we logtransformed the following variables included in the analysis: number of patent authors; $R \& D$ expense; citation of publications; citations on patents; and co-authoring institutions of scientific publications. The mean variance inflation factor is 3.8 , with a maximum of 7.31 , well below the threshold value of 10 , suggesting that our results are not harmed by multicollinearity (Mason and Perreault, 1991).

\section{Results}

Table 2 presents our results, which we now explain in detail before discussing the implications and limitations of this study.

Model 0 includes only control variables. There are two major observations to be made here. First, it is interesting to highlight that of all the different phases in drug discovery, only the number of projects located in the pre-clinical stage correlates positively with the number of out-licensing deals. This finding is consistent with previous studies on optimum licensing strategies for firms in drug discovery (Kalamas and Pinkus, 2003) and complementary to recent industry-led thinking (Paul et al., 2010). Second, the number of failures in R\&D projects is negatively associated with the number of out-licensing deals. This result suggests that failure is viewed negatively by peers in licensing (Edmondson, 2011). Success is important because failed projects are not going to generate out-licensing opportunities in of themselves (though scientific failure might generate reflection opportunities from which future projects could be created). Therefore, the more projects that fail, the less technological knowledge available for the firm to out-license.

In addition, the results also indicate that technology transactions can involve mutual technology transfer in both directions, and the number of in-licensing deals leads to a higher number of out-licensing deals. As discussed previously, we controlled for the effects of number of patents and number of patent authors on the number of out-licensing deals. These two variables are not significant. In addition to controlling for the effect of breadth of $R \& D$ projects, we included the effects of $R \& D$ expenses, firm size and firm age. None of these are significant.

In Model 1 we added the two status variables status by citations on scientific publications and status by citations on patents. This significantly improves the model fit $(\Delta \mathrm{QIC}=-586.866)$. The empirical result suggests that an entrepreneurial firm's status in the public knowledge domain does not have significant impact on the number of out-licensing deals. However, the higher the status an entrepreneurial firm achieves in the private knowledge domain (i.e., higher patent citations), the larger the number of outlicensing deals it can secure. $\mathrm{H}_{1}$ is therefore partially supported.

The insignificant result from status in the public domain is intriguing. The main reason for the insignificance could be that public and private knowledge domains come from different spheres (Arrow, 1962; Merton, 1973; Griliches, 1992). As a result, the high status which an entrepreneurial venture can achieve in the public knowledge domain may have little impact on how the firm will be rewarded in the private knowledge domain (i.e., achieving a larger number of out-licensing deals).

Hypotheses 2 and 3 move on to consider the desorptive capacity of an entrepreneurial venture, by examining the effects of alliance portfolios in both private and public knowledge domains. In this regard, we introduced two new variables in Model 2 to test the predictions. This continues to improve the model fit $(\triangle \mathrm{QIC}=-239.097)$. First, to examine $\mathrm{H}_{2}$, we included a commercial alliances variable. The result supports our prediction, suggesting that a larger number of alliances in the private knowledge domain will lead to more out-licensing deals. Second, we also included a number of co-authoring institutions of scientific publications variable. The result does not support $\mathrm{H}_{3}$. However, this outcome is consistent with the results of $\mathrm{H}_{1}$, where status related to the public knowledge domain does not influence the total number of out-licensing deals in any significant way.

$\mathrm{H}_{4}$ further examines desorptive capacity effects by including the interaction between the two variables of alliance portfolios, in both the private and public knowledge domains. In Model 3, we introduced an interaction term. This further improves the model fit $(\triangle \mathrm{QIC}=-45.519)$. The negative sign of the interaction term supports $\mathrm{H}_{4}$, according to which alliance portfolios in the public knowledge domain negatively moderate the positive effect of alliance portfolios in the private knowledge domain on the number of out-licensing deals.

This result of negative interaction between our two desorptive capacity measures is rather intriguing in light of the context of open innovation. Indeed, it may reflect the risks and challenges related to open innovation, in particular, with out-bound open innovation of out-licensing. As discussed previously, the negative interaction effect finds support from at least three streams of literature in the domains of intellectual property, the market for technology as well as the literature on alliance management. In addition, the negative effect is also consistent with many 
Table 2

Results of regression-drivers of out-licensing deals.

\begin{tabular}{|c|c|c|c|c|c|}
\hline & Model 0 & Model 1 & Model 2 & Model 3 & Model 4 \\
\hline \multicolumn{6}{|l|}{ Control variables } \\
\hline No. of patents & $\begin{array}{l}0.006 \\
(0.005)\end{array}$ & $\begin{array}{l}0.003 \\
(0.004)\end{array}$ & $\begin{array}{l}0.002 \\
(0.004)\end{array}$ & $\begin{array}{l}0.003 \\
(0.004)\end{array}$ & $\begin{array}{l}0.002 \\
(0.004)\end{array}$ \\
\hline No. of patent authors & $\begin{array}{l}0.000 \\
(0.001)\end{array}$ & $\begin{array}{l}0.000 \\
(0.001)\end{array}$ & $\begin{array}{l}0.000 \\
(0.001)\end{array}$ & $\begin{array}{l}0.000 \\
(0.001)\end{array}$ & $\begin{array}{l}0.000 \\
(0.001)\end{array}$ \\
\hline Breadth of R\&D project & $\begin{array}{l}0.264 \\
(0.230)\end{array}$ & $\begin{array}{l}0.059 \\
(0.265)\end{array}$ & $\begin{array}{l}0.010 \\
(0.276)\end{array}$ & $\begin{array}{l}-0.020 \\
(0.271)\end{array}$ & $\begin{array}{c}-0.105 \\
(0.278)\end{array}$ \\
\hline No. of in-licensing deals & $\begin{array}{l}0.047^{* * * *} \\
(0.015)\end{array}$ & $\begin{array}{l}0.035^{\text {*k*k }} \\
(0.017)\end{array}$ & $\begin{array}{l}0.039 * * \\
(0.017)\end{array}$ & $\begin{array}{l}0.030^{*} \\
(0.017)\end{array}$ & $\begin{array}{l}0.016^{*} \\
(0.009)\end{array}$ \\
\hline No. of failed projects & $\begin{array}{l}-0.002^{* * *} \\
(0.001)\end{array}$ & $\begin{array}{l}-0.006^{\text {*** }} \\
(0.003)\end{array}$ & $\begin{array}{l}-0.005^{\text {*** }} \\
(0.002)\end{array}$ & $\begin{array}{l}-0.002^{* * *} \\
(0.001)\end{array}$ & $\begin{array}{l}-0.008^{\text {*** }} \\
(0.004)\end{array}$ \\
\hline R\&D expense & $\begin{array}{l}0.000 \\
(0.000)\end{array}$ & $\begin{array}{l}0.000 \\
(0.000)\end{array}$ & $\begin{array}{l}0.000 \\
(0.000)\end{array}$ & $\begin{array}{l}0.000 \\
(0.000)\end{array}$ & $\begin{array}{l}0.000 \\
(0.000)\end{array}$ \\
\hline Firm age & $\begin{array}{l}0.016 \\
(0.017)\end{array}$ & $\begin{array}{l}0.011 \\
(0.015)\end{array}$ & $\begin{array}{l}0.009 \\
(0.015)\end{array}$ & $\begin{array}{l}0.014 \\
(0.015)\end{array}$ & $\begin{array}{l}0.013 \\
(0.014)\end{array}$ \\
\hline Firm size & $\begin{array}{l}-0.010 \\
(0.145)\end{array}$ & $\begin{array}{l}-0.081 \\
(0.154)\end{array}$ & $\begin{array}{c}-0.150 \\
(0.163)\end{array}$ & $\begin{array}{c}-0.131 \\
(0.159)\end{array}$ & $\begin{array}{l}-0.084 \\
(0.160)\end{array}$ \\
\hline No. of Phase 1 project & $\begin{array}{l}-0.008 \\
(0.010)\end{array}$ & $\begin{array}{l}-0.003 \\
(0.010)\end{array}$ & $\begin{array}{c}-0.005 \\
(0.010)\end{array}$ & $\begin{array}{l}-0.008 \\
(0.010)\end{array}$ & $\begin{array}{l}-0.006 \\
(0.010)\end{array}$ \\
\hline No. of Phase 2 project & $\begin{array}{l}0.011 \\
(0.007)\end{array}$ & $\begin{array}{l}0.002 \\
(0.007)\end{array}$ & $\begin{array}{l}0.001 \\
(0.008)\end{array}$ & $\begin{array}{l}0.004 \\
(0.008)\end{array}$ & $\begin{array}{l}0.001 \\
(0.008)\end{array}$ \\
\hline No. of Phase 3 project & $\begin{array}{l}-0.021 \\
(0.015)\end{array}$ & $\begin{array}{l}-0.006 \\
(0.013)\end{array}$ & $\begin{array}{l}-0.001 \\
(0.014)\end{array}$ & $\begin{array}{l}-0.001 \\
(0.014)\end{array}$ & $\begin{array}{l}0.009 \\
(0.014)\end{array}$ \\
\hline No. of preclinical project & $\begin{array}{l}0.017^{* * * *} \\
(0.003)\end{array}$ & 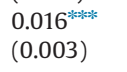 & $\begin{array}{l}0.012^{\text {**** }} \\
(0.004)\end{array}$ & $\begin{array}{l}0.012^{\text {***** }} \\
(0.004)\end{array}$ & $\begin{array}{l}0.009 * * * \\
(0.004)\end{array}$ \\
\hline \multicolumn{6}{|l|}{ Market imperfection and information asymmetry } \\
\hline Status (citations of publications) & & $\begin{array}{l}-0.027 \\
(0.039)\end{array}$ & $\begin{array}{l}-0.047 \\
(0.071)\end{array}$ & $\begin{array}{c}-0.071 \\
(0.071)\end{array}$ & $\begin{array}{l}-0.029 \\
(0.073)\end{array}$ \\
\hline Status (citations of patents) & & $\begin{array}{l}0.257^{\text {***** }} \\
(0.056)\end{array}$ & $\begin{array}{l}0.260^{* * * *} \\
(0.058)\end{array}$ & $\begin{array}{l}0.250^{* * k * k} \\
(0.058)\end{array}$ & $\begin{array}{l}0.206^{\text {*k*kl }} \\
(0.060)\end{array}$ \\
\hline \multicolumn{6}{|l|}{ Desorptive capacity } \\
\hline No. of commercial alliances & & & $\begin{array}{l}0.017^{* * *} \\
(0.006)\end{array}$ & $\begin{array}{l}0.032^{* * * *} \\
(0.008)\end{array}$ & $\begin{array}{l}0.030^{\text {***** }} \\
(0.008)\end{array}$ \\
\hline No. of co-authoring institutions of scientific publications & & & $\begin{array}{l}-0.015 \\
(0.102)\end{array}$ & $\begin{array}{l}-0.008 \\
(0.102)\end{array}$ & $\begin{array}{l}-0.006 \\
(0.104)\end{array}$ \\
\hline No. of Commercial alliances $\times$ No. of Co-authoring institutions of scientific publications & & & & $\begin{array}{l}-0.009^{* * *} \\
(0.003)\end{array}$ & $\begin{array}{l}-0.009^{* * *} \\
(0.003)\end{array}$ \\
\hline Scale of R\&D project & & & & & 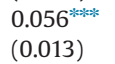 \\
\hline Scale of $R \& D$ project ${ }^{2}$ & & & & & $\begin{array}{l}-0.001^{* *} \\
(0.000)\end{array}$ \\
\hline QIC & 3984.844 & 3397.978 & 3158.881 & 3113.362 & 3097.404 \\
\hline
\end{tabular}

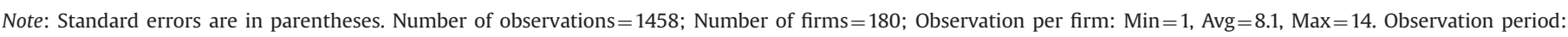
1990-2008. Nineteen calendar-year dummies are also included in all models, but not listed in the table. (Two tailed).

$$
\begin{aligned}
& * p<0.1 \\
& * * p<0.05 \\
& * * * p<0.01
\end{aligned}
$$

empirical observations of the actual conflicts between partners from the public and private knowledge domains. Major issues have been described in detail in a recent commentary on this topic. Gray (2006) captures the essence of the conflict between research collaborations that involve universities, who are primarily focused on generation and dissemination of public knowledge, and commercial partners, who are primarily focused on the generation of knowledge that can capture private economic returns. Gray (2006) observes that “...industry's need to protect intellectual property may run counter to the open-access model of resource sharing encouraged in academia once discoveries have been published." Furthermore, "the increased investment in academia by industry has raised numerous concerns that the potential imposition of corporate secrecy and drive for profits is at odds with academic culture... Many corporate grants come with a requirement for publication delay to allow internal review and filing for patent protection when deemed necessary or desirable... More troubling is the extension of intellectual property rights and the associated restrictions beyond the research actually funded by the company. Some agreements have allowed the industry partner to "cherry pick' a subset of new inventions generated by an entire academic department regardless of whether the discovery was made by a funded investigator"(Gray, 2006, p. 652).

To achieve successful partnerships, the differing cultural and economic needs that exist in both the public and private knowledge domains need to be accommodated. Specifically, for industry, a straightforward and transparent structure for corporate arrangements that defines acceptable parameters for confidentiality, handling of intellectual property, financing and conflict resolution are important. For academia, they need to balance a culture and duty of public disclosure of knowledge through publication against commercial partner's need to capture proprietary intellectual property that can eventually be commercialized (Gray, 2006). Unless these conflicts are resolved, portfolios in the public knowledge domain may negatively moderate the positive effect of alliance portfolios in the private knowledge domain on the number of out-licensing deals.

$\mathrm{H}_{5}$ further refines our hypothesis on desorptive capacity by predicting the learning effect arising from the scale of the R\&D portfolio of entrepreneurial firms. In Model 4, both the linear and 
quadratic term for the scale of R\&D portfolio are added into the regression model. This continues to improve the model fit $(\Delta \mathrm{QIC}=-15.958)$. The positive sign of the linear term and negative sign of the squared term confirm our prediction. As indicated by Fig. 1, the positive effect of the size of R\&D portfolio on the number of new out-licensing deals rises steadily with an increase in the size of a firm's R\&D portfolio, and reaches its peak when the firm has a portfolio of $23 \mathrm{R} \& \mathrm{D}$ projects, after which the positive effect starts to decline. This pattern supports the argument in $\mathrm{H}_{5}$, which suggests an inverted $U$ shape between size of R\&D portfolio and the number of out-licensing deals.

We undertook additional analysis to explore whether the inverted $U$ shape effect we found is driven by the functional form of our modelling procedure or if it is also reflected in the underlying data. We therefore conducted model free analysis, plotting the number of out-licensing deals against the total number of R\&D projects for each observation in our dataset. This analysis is reported in Fig. 2, from which we observe the pattern of this relationship as being an inverted U-shape effect. Observations rise, thin out and then decline.

We estimated alternative models to validate the robustness of the reported results. First, to better understand the implications of some of the firms developing drugs of their own, we estimated models in which we interacted the theoretical variables with the drug dummy variable. None of these interaction effects was significant. Second, we re-estimated the model using different knowledge depreciation parameters in reasonable ranges around $20 \%$, but this did not affect the results either. Third, we explored the presence of interaction

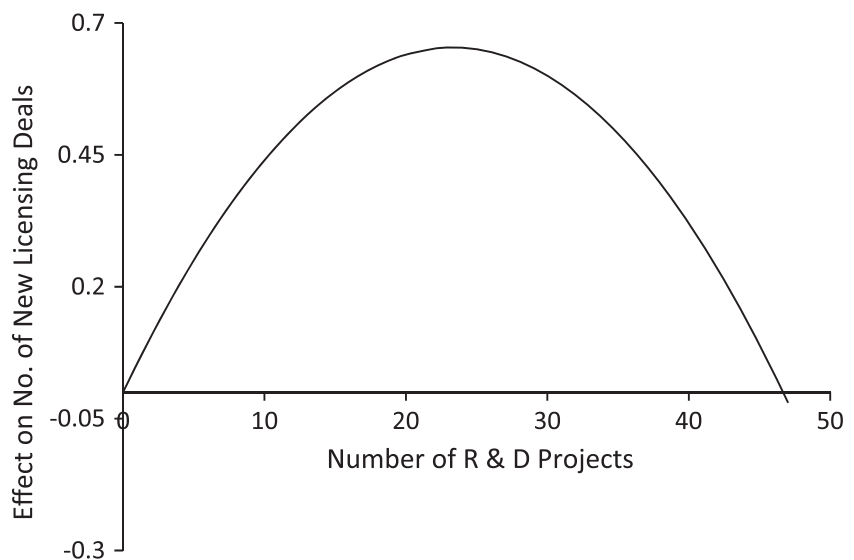

Fig. 1. The inverted-U effect of the size of R\&D portfolios on the number of new licensing deals

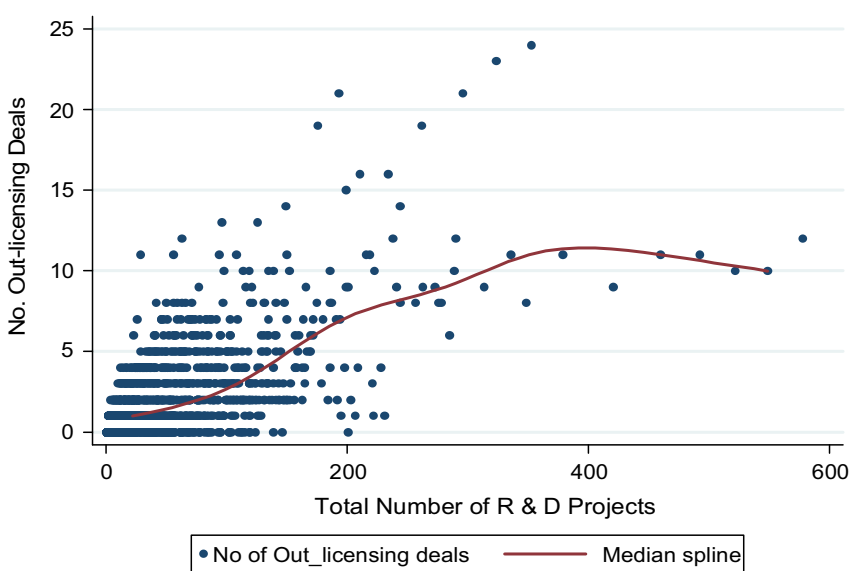

Fig. 2. Model free analysis of the inverted $U$ shape. effects between several of the variables included in the model, such as: alliance portfolios and technological breadth, status, and patents. These interaction effects were not significant however, nor did they increase the explanatory power of the model, or affect the substance of the conclusions derived above. Fourth, we included 19-year dummy variables to account for industry shocks during the period we studied. In particular, we looked for a significant effect during the years when there were powerful shocks in the biotechnology industry. However, none of the time dummies was significant and no other results were affected. Fifth, we have done a robustness check where we let the stock measures of all firms build for a period of four or five years, and the substantive results remain robust. Sixth, we conducted additional analyses by asking the question: How do types of alliance partners (commercial versus noncommercial alliance partners) affect status development (measured by two variables: paper citations and patent citations). As illustrated in Table 3, one interesting result is that a greater number of commercial alliance leads to higher status measured by patent citations. No other effects are significant except for lagged dependent variables which suggest the past status of firms positively influence their current status.

Seventh, we conducted additional analyses by asking the question: How do types of alliance partners (i.e., commercial versus noncommercial alliance) affect the learning opportunities of firms (we use total number of R\&D projects as a proxy for leaning opportunities). The results in Table 4 suggest that number of commercial alliances positively contribute to learning opportunities, and for the number of non-commercial alliances the result is not significant.

Eighth, we further consider the impact of different types of alliances, the number of partners within each alliance and the national contexts of the focal firms. To do so, we look into more fined-tuned features of alliance by distinguishing between alliance consisting of biopharmaceutical and biopharmaceutical firms, and alliance consisting of biopharmaceutical and pharmaceutical firms, and number of partners within each alliance. We added to our Model 0 the following variables: (1) no. of biopharmaceutical-biopharmaceutical alliance,

Table 3

Change in status associated with types of alliances.

\begin{tabular}{|c|c|c|}
\hline & $\begin{array}{l}\mathrm{DV}=\mathrm{Ln} \\
(\text { Papercitations }+1)\end{array}$ & $\begin{array}{l}\mathrm{DV}=\mathrm{Ln} \\
\text { (Patentcitations }+1)\end{array}$ \\
\hline No. of commercial alliance & $-0.0003(0.0034)$ & $0.011^{* * * *}(0.003)$ \\
\hline $\begin{array}{l}\text { No. of non-commercial } \\
\text { alliance }\end{array}$ & $0.003(0.018)$ & $-0.019(0.018)$ \\
\hline Lagged DV & $1.022^{* * * * *}(0.025)$ & $0.612^{\text {**** }}(0.031)$ \\
\hline Firm fixed effects & Yes & Yes \\
\hline Year fixed effects & Yes & Yes \\
\hline Total $R^{2}$ & 0.937 & 0.737 \\
\hline
\end{tabular}

Note: Standard errors in brackets.

$$
\text { *** } p<0.01 \text {. }
$$

Table 4

Learning opportunities associated with types of alliances.

\begin{tabular}{ll}
\hline DV = Learning opportunities (total number of R\&D projects) & \\
\hline No. of commercial alliance & $0.049^{* * *}(0.019)$ \\
No. of non-commercial alliance & $0.039(0.094)$ \\
Lagged DV & $0.631^{* * * *}(0.023)$ \\
Firm fixed effects & Yes \\
Year fixed effects & Yes \\
Total $R^{2}$ & 0.84 \\
\hline
\end{tabular}

Note: Standard errors in brackets.

$$
\text { ** } p<0.05
$$$$
\text { *** } p<0.01 \text {. }
$$ 
(2) no. of biopharmaceutical-pharmaceutical alliance, (3) no. of multiple partners, and (4) 11 countries dummies for the sample firms. None of the effects of these new variables are significant. What is intriguing here is that the country dummies are not significant. One of the reasons contributing to the uniformity of the firms on this issue could be that the firms have strong international presence.

\section{Discussion and conclusion}

Outbound open innovation opens up the innovation process to external knowledge exploitation (Mortara and Minshall, 2011) and brings about both economic and nonmonetary benefits (Arora et al., 2001; Grindley and Teece, 1997). While considerable amount of previous research has focused on licensing as an additional source of revenue for large, established firms, often in the context of international expansion (Fosfuri, 2006; Kotabe et al., 1996), there has been little systematic study on the specific out-licensing challenges faced by entrepreneurial firms which often have not fully integrated their technologies into products. Therefore, the combined findings of this study provide a better understanding of why some entrepreneurial firms obtain a higher number of outlicensing deals than others. Our work has contributed to the literature on outbound open innovation in three ways, each of which we discuss below: the relationship between out-licensing and social status in public and private knowledge domains, failure experience, and the factors that directly influence a firm's ability to out-license knowledge.

Our first contribution is about the understanding of external knowledge exploitation and complement important aspects of literatures on outbound open innovation and desorptive capacity, offering empirically rich insights for bio-pharmaceutical firms into the drivers of the volume of out-licensing deals and the effectiveness of outbound open innovation (Huizingh, 2011).

We clarify whether social status helps entrepreneurial ventures overcome market imperfection and information asymmetry in out-licensing, and further illustrate the importance of specific aspects of social status-building in this process. Prior literature has argued that recognition of a firm's scientific knowledge base in the form of public citation by other knowledge producers, be that basic science published in journals or patented knowledge with private property rights, is an indication of the strength of a firm's technological capabilities (Gittelman and Kogut, 2003). We advance this literature by demonstrating that status in both spheres of knowledge does not equally attract out-licensing partners, which is an important route for the commercialization of an entrepreneurial firm's knowledge base. Social status attached to a firm's pool of private knowledge, or patent citations, is associated with increased out-licensing deals, whilst social status attached to public knowledge, or paper citations, is not. Our study also demonstrates that the same relationship exists for desorptive capacity; greater numbers of prior commercial alliances are associated with higher levels of out-licensing, whilst coauthoring with institutions on scientific publications is not. Thus, out-licensing deals are driven both by recognition of the importance of a firm's private property rights, or patents, and by its prior experience in managing commercial alliances. Out-licensing partners are attracted to a record of success in a firm's ability both to manage alliance relationships, as evidenced by its volume of prior commercial partnerships, and to feed into the deal, not only intellectual property rights but also patents that are recognised in the scientific community as being of high importance and hence potential value.

The literature on the relationship between $R \& D$ failure and performance reports both positive and negative relationships with performance. Positive relationships between failure experience and firm performance have been associated with improvements in exploration for new technology and cases where learning is vicarious (Girotra et al., 2007). Similarly, failure may trigger reflection, and hence improvements in a firm's organizational adaptation and reliability, which are associated with organizational success (Carmeli and Schaubroeck, 2008; Madsen and Desai, 2010). In the bio-pharmaceutical industry it has been found that failure experience stimulates search for new technologies but not new markets (Su and McNamara, 2012). At the same time, there is also evidence of bias against supporting failure with future resource commitments. Failure in collaboration, for example, is associated with negative organizational performance consequences (Lhuillery and Pfister, 2009). Furthermore, financial markets respond negatively to announcements of failure in the new product development process and do so in an asymmetric manner, where stock-market declines in response to failure announcements are many times greater than the positive response to announcements of success in new product development (Sharma and Lacey, 2004).

Taken together, we therefore contribute to the literature on the relationship between failure experience and firm performance, demonstrating that failure experience in R\&D is negatively associated with out-licensing deals. Our study adds to the evidence that whilst failure experience may be associated with the exploration of new technologies, it has a negative relationship with the exploitation and commercialization of technologies. Out-licensing partners are looking for technologies that can be transformed into commercial success in the near future, and failure in clinical experience suggests a return to search for new technologies and a reduced likelihood of commercial success from the current stock of technology in the short term. In the mid- and long-term, repurposing strategy of failures may yet be found to enhance the opportunity in out-licensing. A major focus for drug repurposing is to re-pursue drug candidates that did not succeed in advanced clinical trials, for reasons other than safety, for potential new therapeutic applications (Roy et al. 2011). Drug repurposing is cost-effective as these compounds have the necessary safety profile, and further investigation requires identification of new therapeutic indications (Roy et al. 2011).

In this research, we take a dynamic view of desorptive capacity by examining an entrepreneurial venture's learning process both internally, from its own technology trajectory, and externally, through inter-organizational alliances. Prior outbound open innovation studies do not account for the heterogeneity of technology and experiences of both success and failure with R\&D observed in our study. We demonstrate the contingency effect of a firm's external learning as it builds up its desorptive capacity namely, that co-authoring partners in scientific publications negatively moderate the effect of commercial alliances on the number of outlicensing deals the firm secures. Recent work, that has addressed the issue of interdependencies in alliance portfolios, provides support for the portfolio effect idea (Vassolo et al., 2004). Surprisingly, however, there is a lack of empirical studies on the subject. Therefore, our finding on the interdependence relationship between alliances within the private and public knowledge domains contributes to this area of research.

Concerning manager-oriented insights, we find that the social status of a licensor in the private knowledge domain positively influences the number of new out-licensing deals the firm can obtain, as the firm's status has informational value to licensees. This implies that firm strategies for reducing information asymmetries may reduce the risks of trading technology and hence increase the attractiveness of such firms in the market for technological out-licensing deals. However, the high status which an entrepreneurial firm can achieve in the public knowledge domain may have little impact on how the firm will be rewarded in the private knowledge domain. The insignificant 
effect of social status in the public knowledge domain points to a paradox in technology markets. Publishing a large number of highlycited scientific papers can be useful in terms of bridging the information asymmetry with potential licensees, but it can also signal a lack of concern for confidentiality. Yet, confidentiality is essential because of the innate value of rivalry of intellectual property, suggesting that disclosing an idea to some, substantially reduces its value for others (Gans and Stern, 2010). In licensing exchange, firms ought to strike a balance between informing the market and assuring confidentiality. Too many publications by a firm on a certain topic may also damage the originality of an innovative idea, which in turn can raise concerns about related technologies that the firm intends to license out.

In this paper, we find that if an entrepreneurial firm has a large number or percentage of failed R\&D projects behind it, such failures may negatively impact the total number of its outlicensing deals. Out-licensing partners are likely to be biased towards a recent track record of success and wary of undertaking deals with entrepreneurial firms that have a recent track record of clinical failures. Therefore, entrepreneurial firms should be cautious in taking on a large number of high-risk projects as these may cause potential damage to their reputation, negatively affecting external knowledge exploitation.

In addition, we find that the alliances in the public knowledge domain negatively moderate the positive effect from alliances in the private knowledge domain on the number of out-licensing deals. The findings support the theories on entrepreneurial firms in explaining strategic actions (Rao et al., 2008). In particular, conflict between partners occurs when they affect one another negatively because they are members of competing networks and/ or are strong rivals in an industry and/or promote competing technologies (Wassmer, 2010). Entrepreneurial firms should minimize these potential conflicts in their alliance portfolios.

Finally, because of the high degree of uncertainty affecting drug discovery, entrepreneurial firms may find it quite tempting to carry on a large number of projects so that they can learn through trial and error to build stronger desorptive capacity. However, our examination reveals that an inverted $U$ shape exists between the total number of R\&D projects and the number of out-licensing deals. Such an effect can be explained by the knowledge intensive nature of the out-licensing process, the diversity of tasks involved and the varying conditions of uncertainty where the commercialisation may occur (Chesbrough, 2003), which require individuals to be central actors of its implementation. Large firms, such as Procter \& Gamble (Palomeras, 2007), have managed to substantially increase licensing revenues only after establishing a panel of multidisciplinary technologists, responsible for identifying applications for proprietary technologies. However, for entrepreneurial firms, organization of out-licensing tasks can be a challenge, since these tasks are shaped by the volume of out-licensing transactions, the stage of development of the technology being commercialized and the competitive threats due to the deal (Bianchi et al., 2011b). Therefore, working on too many tasks simultaneously causes less attention to be paid to any individual task (Navon and Gopher, 1979). Likewise, when multiple tasks need the same resources at the same time, bottlenecks arise, and all tasks are impaired (DeJong, 1993; Pashler, 1994). Recent study has also found that the difficulty in finding partners is the primary factor behind a substantial number of unlicensed patents, despite the owners' willingness to license out (Kani and Motohashi, 2012). Overall, these arguments suggest that processing too many tasks at the same time is likely to lead to lower performance output in innovation.

As with many early studies in an area, this research has several limitations, some of which offer fruitful avenues for further research. First, because of data limitations, we examine out-licensing behaviours in the bio-pharmaceutical industry alone. While many of the arguments might also hold for medium and large organizations, further research is needed to test the hypotheses in other contexts, such as electronics and telecommunications. Second, in our examination of desorptive capacity, we have included both firms' internal factors (R\&D portfolios) and external factors (alliance portfolios). However, we were unable to conduct a detailed analysis of the learning process where firms build on market knowledge to help out-licensing. Future studies may explore the construct of desorptive capacity and its impact on outbound innovation in more depth. A longitudinal survey may prove useful in this regard.

\section{Acknowledgements}

This research is partially funded under the Programme for Research in Third-Level Institutions and co-funded under the European Regional Development fund as part of the Innovation Policy Simulation for the Smart Economy (IPSE) research project on which Peter Mc Namara is one of the Principal Investigators.

\section{References}

Akerlof, G.A., 1970. The market for "lemons": quality uncertainty and the market mechanism. Q. J. Econ. 84 (3), 488-500.

Allarakhia, M., Walsh, S., 2011. Managing knowledge assets under conditions of radical change: the case of the pharmaceutical industry. Technovation 31 , 105-117.

Ancona, D.G., Goodman, P.S., Lawrence, B.S., Tushman, M.L., 2001. Time: a new research lens. Acad. Manage. Rev. 26, 645-663.

Arnold, K., Coia, A., Saywell, S., Smith, T., Minick, S., Löffler, A., 2002. Value drivers in licensing deals. Nat. Biotechnol. 20, 1085-1089.

Arora, A., Fosfuri, A., Gambardella, A., 2001. Markets for Technology: The Economics of Innovation and Corporate Strategy. MIT Press, Cambridge.

Arora, A., Gambardella, A., 2010. Ideas for rent: an overview of markets for technology. Ind. Corp. Change 19 (3), 775-803.

Arrow, K.J., 1962. Economic welfare and the allocation of resources for invention. In: Nelson, R. (Ed.), The Rate of Direction of Inventive Activity. Princeton University Press, Princeton, NJ.

Bamford, J.D., Ernst, D., 2002. Managing an alliance portfolio. McKinsey Q. 3, 29-39.

Baum, J.A.C., Dahlin, J.K.B., 2007. Aspiration performance and railroads' patterns of learning from train wrecks and crashes. Organiz. Sci. 18 (3), 368-385.

Bianchi, M., Cavaliere, A., Chiaroni, D., Frattini, F., Chiesa, V., 2011a. Organisational modes for open innovation in the bio-pharmaceutical industry: an exploratory analysis. Technovation 31 (1), 22-33.

Bianchi, M., Chiaroni, D. Chiesa, V., Frattini, F, 2011b. Organizing for external technology commercialization: evidence from a multiple case study in the pharmaceutical industry. R\&D Manage. 41 (2), 120-131.

Bidault, F., Fischer, W.A., 1994. Technology transactions: networks over markets. R\&D Manage. 24, 373-386.

Bluedorn, A.C., Kaufman, C.F., Lane, P.M., 1992. How many things do you like to do at once? An introduction to monochronic and polychronic time. Acad. Manage Exec. 6 (4), 17-26.

Burgelman, R.A., 2002. Strategy as vector and the inertia of coevolutionary lock-in. Adm. Sci. Q. 47, 325-357.

Burt, R.S., 1982. Toward a Structural Theory of Action. Academic Press, New York, NY.

Business Insights, 2009. Evolving trends in biopharmaceutical licensing: deal assessments, drivers and resistors. Business Insights. 01 Mar 2009, BI00027020.

Cantwell, J., 2004. An historical change in the nature of corporate technological diversification. In: Cantwell, J., Garmbardella, A., Granstrand, O. (Eds.), The Economies and Management of Technological Diversification. Routledge, London, pp. 265-296.

Carmeli, A., Schaubroeck, J., 2008. Organizational crisis preparedness: the importance of learning from failure. Long Range Plann. 41 (2), 177-196.

Chandy, R., Hopstaken, B., Narasimhan, O., Prabhu, J, 2006. From invention to innovation: Conversion ability in product development. J. Mark. Res. 43 (3), 494-508.

Chesbrough, H., 2003. Open Innovation: The New Imperative for Creating and Profiting from Technology. Harvard Business School Press, Boston.

Cockburn, I., Henderson, R.M., Orsenigo, L., Pisano, G., 1999. Pharmaceuticals and biotechnology. In: Mowery, D. (Ed.), U.S. Industry in 2000: Studies in Competitive Performance. National Academy Press, Washington, DC, pp. 363-398.

Cohen, W.M., Levinthal, D., 1990. Absorptive capacity: a new perspective on learning and innovation. Adm. Sci. Q. 35, 128-152.

Contractor, F.J., Lorange, P., 2002. The growth of alliances in the knowledge-based economy. Int. Bus. Rev. 11 (4), 485-502.

Dacin, M.T., Oliver, C., Roy, J.-P., 2007. The legitimacy of strategic alliances: an institutional perspective. Strateg. Manage. J. 28, 169-187.

DeJong, R., 1993. Multiple bottlenecks in overlapping task performance. J. Exp. Psychol.: Hum. Percept. Perform. 19 (5), 965-980. 
Dosi, G., 1982. Technological paradigms and technological trajectories. Res. Policy $11,147-162$.

Edmondson, A., 2011. Strategies for learning from failure. Harv. Bus. Rev. 89 (4), $48-55$

Eggers, J.P., Kaplan, S., 2009. Cognition and renewal: comparing ceo and organizational effects on incumbent adaptation to technical change. Organ. Sci. 20, 461-477.

Enkel, E., Gassmann, O., Chesbrough, H., 2009. Open R\&D and open innovation: exploring the phenomenon. R\&D Manage. 39 (4), 311-316.

Fleming, L., Sorenson, O., 2001. Technology as a complex adaptive system: evidence from patent data. Res. Policy 30, 1019-1039.

Ford, D., Thomas, R., 1997. Technology strategy in networks. Int. J. Technol. Manage. 14, 596-612.

Fosfuri, A., 2006. The licensing dilemma: understanding the determinants of the rate of technology licensing. Strateg. Manage. J. 27, 1141-1158.

Fosfuri, A., Giarratana, M.S., 2010. Introduction: trading under the Buttonwood: a foreword to the markets for technology and ideas. Ind. Corp. Change 19, 767-773.

Gambardella, A., Giuri, P., Luzzi, A., 2007. The market for patents in Europe. Res. Policy 36 (8), 1163-1183.

Gans, J.S., Stern, S., 2010. Is there a market for ideas? Ind. Corp. Change 19 (3), 805-837.

Garud, R., Karnoe, P., 2002. Path Dependency and Creation. LEA Publishers, London.

Gassmann, O., Enkel, E., Chesbrough, H., 2010. The future of open innovation. R\&D Manage. 40 (3), 213-221.

Giannopoulou, E., Ystrom, A., Elmquist, M., Fredberg, T., Ollila, S., 2010. Implications of openness: a study into (all) the growing literature on open innovation. J. Technol. Manage. Innov. 5 (3), 162-180.

Gimeno, J., 2004. Competition within and between networks: the contingent effect of competitive embeddedness on alliance formation. Acad. Manage. J. 47, $820-842$.

Girotra, K., Terwiesch, C., Ulrich, K.T., 2007. Valuing R\&D projects in a portfolio: evidence from the pharmaceutical industry. Manage. Sci. 53 (9), 1452-1466.

Gittelman, M., Kogut, B., 2003. Does good science lead to valuable knowledge? Biotechnology firms and evolutionary logic of citation patterns. Organ. Sci. 49 (4), 366-382.

Gomes-Casseres, B., 1996. The Alliance Revolution: The New Shape of Business Rivalry. Harvard University Press, Cambridge, MA

Gould, R.V., 2002. The origins of status hierarchies: a formal theory and empirical test. Am. J. Sociol. 107, 1143-1178.

Gray, N.S., 2006. Drug discovery through industry-academic partnerships. Nat. Chem. Biol. 2 (12), 649-653.

Griliches, Z., 1990. Patent statistics as economic indicators: a survey. J. Econ. Lit. 18 (4), 1661-1707.

Griliches, Z., 1992. The search for R\&D spillovers. Scand. J. Econ. 94, S29-S47.

Grindley, P.C., Teece, D.J., 1997. Managing intellectual capital: licensing and crosslicensing in semiconductors and electronics. Calif. Manage. Rev. 39, 8-41.

Groen, A.J., Linton, J.D., 2010. Is open innovation a field of study or a communication barrier to theory development? Technovation 30 (11-12), 554.

Gulati, R., 1998. Alliances and networks. Strateg. Manage. J. 19, 293-318.

Gulati, R., Singh, H., 1998. The architecture of cooperation: managing coordination costs and appropriation concerns in strategic alliances. Adm. Sci. Q. 43 (4), 781-814.

Gupta, A.K., Smith, K.G., Shalley, C.E., 2006. The interplay between exploration and exploitation. Acad. Manage. J. 4, 693-706.

Harhoff, D.F., Narin, F.M., Vopel, K.V., 1999. Citation frequency and the value of patented inventions. Rev. Econ. Stat. 81 (3), 511-515.

Hausman, J., Hall, B.H., Griliches, Z., 1984. Econometric models for count data with an application to the patents-R\&D relationship. Econometrica 52 (4), 909-938.

Helfat, C.E., Finkelstein, S., Mitchell, W., Peteraf, M.A., Singh, H., Teece, D.J., Winter, S.G., 2007. Dynamic Capabilities: Understanding Strategic Chance in Organizations. Blackwell, Oxford.

Hoegl, M., Wagner, S.M., 2005. Buyer-supplier collaboration in product development projects. J. Manage. 31, 530-548.

Hoffmann, W.H., 2007. Strategies for managing a portfolio of alliances. Strateg. Manage. J. 28, 827-856.

Holmqvist, M., 2004. Experiential learning: the contributing process and the literatures. Organ. Sci. 2, 88-115.

Huizingh, E.K.R.E., 2011. Open innovation: state of the art and future perspectives. Technovation 31 (1), 2-9.

Irwin, D., Klenow, P., 1994. Learning-by-doing spillovers in the semiconductor industry. J. Polit. Econ. 102 (6), 1200-1227.

Jensen, M., 2003. The role of network resources in market entry: Commercial banks' entry into investment banking, 1991-1997. Adm. Sci. Q. 48, 466-497.

Jensen, M., Roy, A., 2008. Staging exchange partner choices: when do status and reputation matter? Acad. Manage. J. 51, 495-516.

Jensen, R., Thursby, M., 2001. Proofs and prototypes for sale: the licensing of university inventions. Am. Econ. Rev. 91 (1), 240-259.

Kalamas, J., Pinkus, G., 2003. The optimum time for drug licensing. Nat. Rev. Drug Discovery 2, 691-692.

Kani, M., Motohashi, K., 2012. Understanding the technology market for patents: new insights from a licensing survey of Japanese firms. Res. Policy 41, 226-235.

Kinsbourne, M., 1981. Single channel theory. In: Holding, D. (Ed.), Human Skills John Wiley \& Sons, New York, NY, pp. 65-89.

Kotabe, M., Sahay, A., Aulakh, P.S., 1996. Emerging role of technology licensing in the development of global product strategy: conceptual framework and research propositions. J. Mark. 60 (1), 73-88.
Lavie, D., Rosenkopf, L., 2006. Balancing exploration and exploitation in alliance formation. Acad. Manage. J. 49 (4), 797-818.

Levinthal, D., March, J., 1993. Myopia of learning. Strateg. Manage. J. 14, 95-112.

Levitas, E., McFadyen, M.A., 2009. Managing liquidity in research-intensive firms: signalling and cash flow effects of patents and alliance activities. Strateg. Manage. J. 30, 659-678.

Lhuillery, S., Pfister, E., 2009. R\&D cooperation and failures in innovation projects: empirical evidence from French CIS data. Res. Policy 38 (1), 45-57.

Madsen, P.M., Desai, V., 2010. Failing to learn? The effects of failure and success on organizational learning in the global orbital launch vehicle industry. Acad. Manage. J. 53 (3), 451-476.

March, J.G., 1991. Exploration and exploitation in organizational learning. Organ. Sci. 2, 71-87.

Mason, C.H., Perreault Jr., W.D., 1991. Collinearity, power, and interpretation of multiple regression analysis. J. Mark. Res. 28 (3), 268-280.

McNamara, P., Baden-Fuller, C., 1999. Lessons from the Celltech case: balancing knowledge exploration and exploitation in organisational renewal. Br. J. Manage. 10 (4), 291-307.

Merton, R.K., 1968. Social Theory and Social Structure. Free Press, New York, NY.

Merton, R.K. 1973. The normative structure of science. In: Storer, N.W. (Ed.) The Sociology of Science: Theoretical and Empirical Investigations. University of Chicago Press, Chicago, pp. 267-280.

Mortara, L., Minshall, T., 2011. How do large multinational companies implement open innovation? Technovation 31 (10-11), 586-597.

Müller-Seitz, G., 2012. Absorptive and desorptive capacity - related practices at the network level - the case of SEMATECH. R\&D Manage. 42 (1), 90-99.

Nair, S.S., Mathew, M., Nag, D., 2011. Dynamics between patent latent variables and patent price. Technovation 31, 648-654.

Navon, D., Gopher, D., 1979. On the economy of the human processing system. Psychol. Rev. 86 (3), 254-284.

Navon, D., Miller, J.O., 1987. Role of outcome conflict in dual-task interference. J. Exp. Psychol.: Hum. Percept. Perform. 13 (3), 435-448.

Palomeras, N., 2007. An analysis of pure-revenue technology licensing. J. Econ. Manage. Strategy 16 (4), 971-994.

Parise, S., Casher, A., 2003. Alliance portfolios: designing and managing your network of business-partner relationships. Acad. Manage. Exec. 17 (4), 25-39.

Pashler, H., 1994. Dual-task interference in simple tasks: data and theory. Psychol. Bull. 116 (2), 220-244.

Paul, S., Mytelka, D., Dunwiddie, C., Persinger, C., Munos, B., Linbory, S., Schacht, A., 2010. How to improve R\&D productivity: the pharmaceutical industry's grand challenge. Nat. Rev. Drug Discovery 9, 203-214.

Perrow, C., 1961. Organizational prestige: some functions and dysfunctions. Am. J. Sociol. 66, 335-341.

Phillips, D.J., Zuckerman, E.W., 2001. Middle-status conformity: theoretical restatement and empirical demonstration in two markets. Am. J. Sociol. 107, 379-429.

Pisano, G., 1997. The Development Factory. Harvard Business School Press, Boston, MA.

Podolny, J.M., 1993. A status-based model of market competition. Am. J. Sociol. 98, 829-872.

Podolny, J., Stuart, T., 1995. A role-based ecology of technological change. Am. J. Sociol. 100, 1224-1260.

Podolny, J.M., 2005. Status Signals: A Sociological Study of Market Competition. Princeton University Press, Princeton, NJ.

Powell, W.W., Koput, K.W., Smith-Doerr, L., 1996. Interorganizational collaboration and the locus of innovation: networks of learning in biotechnology. Adm. Sci. Q. 41 (1), 116-145.

Rao, R.S., Chandy, R.K., Prabhu, J.C., 2008. The fruits of legitimacy: why some new ventures gain more from innovation than others. J. Mark. 72 (4), 58-75.

Rosenberg, N., 1982. Inside the Black Box: Technologies and Economics. Cambridge University Press, Cambridge, UK.

Rothaermel, F.T., Deeds, D.L., 2004. Exploration and exploitation alliances in biotechnology. Strateg. Manage. J. 25, 201-221.

Roy, A., McDonald, P.R., Chaguturu, R., 2011. Recent trends in collaborative, open source drug discovery. Open Conf. Proc. J. 2011 (2), 130-136.

Sharma, A., Lacey, N., 2004. Linking product development outcomes to market valuation of the firm: the case of the US pharmaceutical industry. J. Prod. Innov. Manage. 21 (5), 297-308.

Silverman, B.S., Baum, J.A.C., 2002. Alliance-based competitive dynamics. Acad. Manage. J. 45, 791-806.

Stuart, T.E., 2000. Interorganizational alliances and the performance of firms: a study of growth and innovation rates in a high-technology industry. Strateg. Manage. J. 21, 791-911.

Stuart, T.E., Hoang, H., Hybels, R.C., 1999. Interorganizational endorsements and the performance of entrepreneurial ventures. Adm. Sci. Q. 44, 315-349.

Stuart, T.E., Ozdemir, S.Z., Ding, W.W., 2007. Vertical alliance networks: The case of university-biotechnology-pharmaceutical alliance chains. Res. Policy 36, 477-498.

Su, P., McNamara, P., 2012. Exploration and exploitation within and across intraorganizational domains and their reactions to firm-level failure. Technol. Anal. Strateg. Manage. 24 (2), 129-149.

Teece, D.J., 1998. Capturing value from knowledge assets: the new economy, markets for know-how, and intangible assets. Calif. Manage. Rev. 40 (3), 55-79.

Teece, D.J., 2000. Managing Intellectual Capital: Organizational, Strategic, and Policy Dimensions. Oxford University Press, Oxford.

Teece, D.J., 2007. Explicating dynamic capabilities: the nature and microfoundations of (sustainable) enterprise performance. Strateg. Manage. J. 28 (13), 1319-1350. 
Van de Vrande, V., de Man, A., 2011. A response to "is open innovation a field of study or a communication barrier to theory development. Technovation 31 , 185-186.

Vassolo, R.S., Anand, J., Folta, T.B., 2004. Non-additivity in portfolios of exploration activities: a real options-based analysis of equity alliances in biotechnology. Strateg. Manage. J. 25, 1045-1061.

Wassmer, U., 2010. Alliance portfolios: a review and research agenda. J. Manage. 36 (1), 141-171.
Williamson, O.E., 1975. Markets and Hierarchies: Analysis and Antitrust Implications. The Free Press, New York, NY.

Zeckhauser, R., 1996. The challenge of contracting for technological information. Proc. Nat. Acad. Sci. U.S.A. 93 (23), 12743-12748.

Zeger, S.L., Liang, K.Y., 1986. The analysis of discrete and continuous longitudinal data. Biometrics 42, 121-130.

Zucker, L.G., Darby, M.R., Brewer, M.B., 1998. Intellectual human capital and the birth of U.S. biotechnology enterprises. Am. Econ. Rev. 88 (1), 290-306. 